\title{
PRAKTIK PEKERJAAN SOSIAL BERBASIS HAK ASASI MANUSIA
}

\author{
Oleh: \\ Meilanny Budiarti Santoso ${ }^{1}$ dan Nurliana Cipta Apsari ${ }^{2}$
}

1. Staf Pengajar pada Departemen Kesejahteraan Sosial FISIP Universiitas Padjadjaran

2. Staf Pengajar dan Sekretaris pada Departemen Kesejahteraan Sosial FISIP Universiitas Padjadjaran

Email:

meilannybudiarti13@gmail.com dan nurliana.apsari@gmail.com

\begin{abstract}
Abstrak
Jika orang dianggap memiliki hak, maka hal ini ada implikasinya dengan kewajiban, baik negara maupun individu, untuk memastikan bahwa hak-hak tersebut dilindungi dan diwujudkan. Tulisan ini bermaksud menjelaskan bagaimana Hak Asasi Manusia (HAM) digunakan sebagai dasar untuk praktik pekerjaan sosial. Praktik pekerjaan sosial berbasis HAM muncul sebagai alternatif pendekatan praktik yang sejak pertama kali pembentukan profesi pekerjaan sosial ini mengandalkan pada pemenuhan kebutuhan individu. Metode yang digunakan adalah studi kepustakaan yang berkaitan dengan praktik-praktik pekerjaan sosial berbasis hak asasi manusia. Praktik pekerjaan sosial berbasis HAM perlu dikaji secara rinci, karena dalam praktik pekerjaan sosial, hak dan kewajiban memiliki implikasi yang signifikan demi tercapainya keadilan sosial bagi setiap individu. Praktik pekerjaan sosial dengan menggunakan pendekatan berbasis hak dilaksanakan berdasarkan tiga generasi hak. Dengan menggunakan pendekatan berbasis hak, pekerja sosial telah mengangkat harkat dan martabat klien sebagai individu dan mendorong setiap individu untuk berperan aktif dalam mengidentifikasi dan menggunakan potensi yang ada pada dirinya dan lingkungannya untuk menghadapi tantangan yang mereka alami. Praktik pekerjaan sosial berdasarkan hak membantu individu mengatasi tantangan keberfungsian sosial mereka dan memfasilitasi mereka mendapatkan keadilan sosial.
\end{abstract}

Kata kunci: Praktik Pekerjaan Sosial, Pendekatan berbasis hak, keberfungsian sosial, keadilan sosial

\begin{abstract}
When people is considered to have rights, will be relating wth duty, either the government or the individual need to ensure that those rights are protected and fulfilled. The article explains how the human rights serve as the basis for social work practice. Rights based social work practice emerge as an alternative of practice approach which since its early establishment, the social work profession relying on the achievement of individual needs fullfilment. The methode is literature studies of sources on human rights based social work practices. Rights based approach of social work practice need to be examined closely, because within the practice, rights and duties play significantly in the achievement of social justice for every individual. Rights based social work practice is based on three generations of rights. Using rights based approach, the social worker has uplift the dignity and self worth of the client as an individual and encourage every individual to take on an active role in
\end{abstract}


identifying and utilizing the potential exist within themselves and within the environment to address the challenge they face. Social work practice based on rights assist individual overcoming the challenge of their social functioning and facilitate them gaining the social justice.

Keywords: social work practice, rights based approach, social functioning, social justice

\section{Pendahuluan}

Pekerjaan sosial adalah profesi yang mendasarkan dirinya pada nilai. Nilai-nilai yang diimplementasikan dalam praktik pekerjaan sosial secara tidak langsung sebenarnya telah menghormati hak-hak manusia sebagai fokus dari profesi pekerjaan sosial ini. Hak asasi manusia tidak hanya menjadi dominasi profesi hukum atau politik saja (Apsari, 2015), tetapi pekerjaan sosial pun menggunakan HAM terutama jika dilihat dari 3 generasi HAM sebagaimana yang dijelaskan oleh Ife (2001) dalam Apsari (2015: 6-7) berikut ini:

Tabel 1

Tiga Generasi Hak Asasi

\begin{tabular}{|c|c|c|c|}
\hline & Generasi Pertama & Generasi Kedua & Generasi ketiga \\
\hline Nama & Hak Sipil dan Politik & $\begin{array}{l}\text { Hak Ekonomi, Sosial dan } \\
\text { Budaya }\end{array}$ & Hak Kolektif \\
\hline Asal & Liberalis-me & $\begin{array}{l}\text { Sosialis-me; Demokra-si } \\
\text { Sosial }\end{array}$ & $\begin{array}{l}\text { Ekonomi; Studi } \\
\text { Pembangun-an; Ideologi } \\
\text { Green }\end{array}$ \\
\hline $\begin{array}{l}\text { Con- } \\
\text { toh }\end{array}$ & $\begin{array}{l}\text { Hak untuk memilih, } \\
\text { kebebas-an berpidato, } \\
\text { peng-adilan yang lebih } \\
\text { adil, kebebas-an dari } \\
\text { penyiksa-an, keke- } \\
\text { rasan;hak untuk perlindu- } \\
\text { ngan dari hukum; kebebas- } \\
\text { an dari diskri-minasi }\end{array}$ & $\begin{array}{l}\text { Hak untuk pendidikan, } \\
\text { perumahan,kesehatan, } \\
\text { pekerjaan, pendapat-an } \\
\text { yang cukup, jaminan } \\
\text { sosial, dll }\end{array}$ & $\begin{array}{l}\text { Hak untuk perkemba-ngan } \\
\text { ekonomi dan kekayaan, } \\
\text { mendapat-kan keuntungan } \\
\text { dari pertum-buhan eko- } \\
\text { nomi, har-moni sosial, } \\
\text { lingkungan yang sehat, air } \\
\text { bersih, dll }\end{array}$ \\
\hline $\begin{array}{l}\text { Lemba } \\
\text { ga }\end{array}$ & $\begin{array}{l}\text { Lembaga Bantuan Hukum; } \\
\text { Amnesty Internasional; } \\
\text { Pengawasan Hak Asasi; } \\
\text { bekerja dengan pengung-si }\end{array}$ & $\begin{array}{l}\text { Negara kesejahte-raan; } \\
\text { sektor ketiga; kesejahte- } \\
\text { raan pasar swasta }\end{array}$ & $\begin{array}{l}\text { Lembaga perkemba-ngan } \\
\text { ekonomi; proyek } \\
\text { masyarakat, Greenpeace, } \\
\text { dll }\end{array}$ \\
\hline $\begin{array}{l}\text { Profesi } \\
\text { domin } \\
\text { an }\end{array}$ & Hukum & Pekerjaan Sosial & $\begin{array}{l}\text { Pengemba-ngan } \\
\text { Masyarakat }\end{array}$ \\
\hline $\begin{array}{l}\text { Peker- } \\
\text { jaan } \\
\text { Sosial }\end{array}$ & $\begin{array}{l}\text { Advokasi; Peng-ungsian; } \\
\text { Pencari Suaka; Reforma-si } \\
\text { Penjara, dll }\end{array}$ & $\begin{array}{l}\text { Layanan langsung; } \\
\text { Manaje-men Negara } \\
\text { Kesejahte-raan; } \\
\text { Pengembangan Kebijakan } \\
\text { dan Advokasi; Penelitian }\end{array}$ & $\begin{array}{l}\text { Pengemba-ngan } \\
\text { Masyarakat, Sosial } \\
\text { ekonomi, politik, budaya, } \\
\text { lingkungan, personal/ } \\
\text { spiritual }\end{array}$ \\
\hline
\end{tabular}

Sumber: Apsari (2015: 6-7)

Tabel 1 tersebut menunjukkan bahwa dalam praktiknya profesi pekerjaan 
sosial selalu mempertimbangkan hak asasi manusia, terutama bagi kelompok populasi yang rentah mendapatkan perlakuan yang tidak sesuai dengan HAM. Landasan konsep tiga generasi hak tersebut digunakan oleh seorang pekerja sosial profesional untuk menentukan peran dan fungsinya sebagai fasilitator pencapaian hak seseorang. Namun demikian, seringkali, "bahasa hak" adalah terkesan individualistis, sangat egois. Ungkapan "Saya menuntut hak saya", "Kami menuntut hak kami”, seolah tanpa mempertimbangkan keberadaan hak orang lain.

Jika HAM bersifat universal, maka seorang individu tidak hanya berhak untuk mendapatkan hak-haknya, tetapi juga harus menghormati hak orang lain dan memungkinkan orang lain untuk mendapatkan hak-haknya tersebut. Menerima kerangka hak, berarti tidak dapat diartikan hanya sikap egois pada bagian diri individu saja, menuntut hanya untuk diri sendiri sambil tidak menghargai hak orang lain. Ife (2008) menyebutkan adanya kritik terhadap HAM salah satunya adalah keegois-an, yang menyebutkan bahwa individu menyebutkan dirinya berhak untuk sesuatu, padahal sesuatu tersebut hanya menunjukkan 'keinginan' dirinya sendiri saja, seperti misalnya hak untuk jalan-jalan dengan fasilitas mewah, hak untuk mendengarkan radio dengan suara keras, dll yang sebenarnya tidak mempengaruhi jati diri orang tersebut sebagai manusia.
Ini menunjukkan ada keterkaitan kewajiban setiap anggota masyarakat untuk menghormati dan mendukung hak-hak orang lain. Dalam hal ini, HAM tidak bersifat individualistik, tetapi juga membentuk dasar untuk kolektivisme:

1. Masyarakat diselenggarakan bersama oleh saling menghormati HAM semua warganya dan didasarkan pada gagasan saling membutuhkan,

2. Saling mendukung dan kesejahteraan kolektif.

Dengan demikian, berbicara mengenai konsep HAM, artinya tidak hanya berbicara mengenai "apa yang diperlukan untuk membuat seseorang menjadi manusia sepenuhnya", tapi mereka juga "perlu untuk menjadikan manusia sebagai satu masyarakat yang sepenuhnya manusia”. Kita tidak hanya memiliki HAM untuk kepentingan diri kita sendiri, tetapi untuk kepentingan masyarakat di mana kita hidup dan untuk ke-manusia-an secara keseluruhan.

Tulisan ini dimaksudkan untuk mengupas apa itu praktik pekerjaan sosial berbasis hak dan bagaimana praktik pekerjaan sosial berbasis hak dapat diimplementasikan oleh para pekerja sosial profesional.

\section{Pembahasan}

Dalam praktiknya, profesi pekerjaan sosial sangat berhubungan dengan HAM, Ada beberapa pendekatan yang digunakan yang tidak mengkaitkan praktik pekerjaan sosial 
dengan HAM. Salah satunya adalah Needsbased approach (Pendekatan Berbasis Kebutuhan). Pendekatan Berbasis Kebutuhan menekankan pada bagaimana seorang pekerja sosial mampu mengidentifikasi kebutuhan klien untuk kemudian melakukan proses mempertemukan kebutuhan tersebut dengan sistem sumber yang ada. Pendekatan ini menempatkan pekerja sosial sebagai seorang yang lebih memahami kebutuhan klien daripada klien itu sendiri, sehingga dengan demikian, pendekatan ini tidak memberdayakan dan membuat klien berada dalam posisi pasif menerima apa yang telah diidentifikasi oleh pekerja sosial tersebut. Praktik berbasis kebutuhan telah merepresentasikan formula alternatif bagi seorang pekerja sosial dalam praktik berbasis HAM.

Sementara itu, a right-based approach (Pendekatan Berbasis Hak) menekankan pada pemahaman bahwa setiap manusia semenjak lahir telah memiliki hak yang melekat pada dirinya. Pendekatan berbasis hak dikembangkan untuk mencapai keadilan sosial (Apsari, 2015: 70). Fenomena keadilan sosial pun dimaknai beragam oleh masyarakat dan hal ini terkait dengan perbedaan antara konsep yang diusung oleh pendekatan retributif dan pendekatan restoratif terkait istilah keadilan (Fatic, 1995).

Pendekatan retributif mencari retribusi: mereka yang telah melanggar hukum, bertindak amoral atau melakukan pelanggaran hak asasi manusia, berdasarkan pendekatan retributif harus diidentifikasi, diburu, dan dibuat untuk 'membayar' atas kejahatankejahatan yang telah mereka lakukan. Ini adalah berkomitmen pendekatan retributif, yaitu dengan menuntut retribusi dari pelaku untuk menebus keadilan atas tindakan yang telah dilakukan. Hal ini menghasilkan hukuman bagi pelaku dan juga sebagai upaya pencegah bagi orang lain agar tidak melakukan tindakan serupa.

Pendekatan restoratif lebih mengakui bahwa kesalahan telah dilakukan dan berupaya melakukan tindakan yang memungkinkan semua pihak dapat terlibat untuk bergerak maju dalam semangat rekonsiliasi. Kondisi kontras diantara kedua pendekatan tersebut, mudah digambarkan dalam pendekatan yang bertentangan dengan kekejaman HAM seperti yang terjadi di Kamboja, Rwanda, Timor Timur dan bekas Yugoslavia. Dalam situasi tersebut, pendekatan retributif berusaha untuk mendirikan pengadilan kejahatan perang atau badan peradilan lain sehingga yang bersalah harus dihukum dan 'dibawa ke pengadilan', sedangkan pendekatan restoratif berusaha untuk lebih menghadapi pelanggar hak asasi manusia dengan kejahatan mereka, mencari pengakuan publik atas mereka, dan kemudian bergerak maju, sebagaimana dicontohkan oleh proses Kebenaran dan Rekonsiliasi di Afrika Selatan (Tutu 1999).

Terlepas dari pendekatan retributif atau restoratif, definis HAM dalam praktik 
pekerjaan sosial dapat dicirikan ke dalam 5 karakteristik sebagaimana yang disebutkan oleh Ife (2001) dalam Apsari (2015: 71) yaitu:

1. Realisasi hak yang disebut sebagai hak asasi adalah penting bagi seseorang atau sekelompok orang sehingga mereka mampu mencapai ke-manusia-an mereka

2. Hak yang dinyatakan dapat berlaku bagi semua manusia atau berlaku bagi kelompok orang-orang kurang beruntung atau terpinggirkan, yang mana pemenuhan hak tersebut menjadi penting demi kemanusia-an mereka

3. Ada konsensus yang berlaku secara universal

4. Hak tersebut mampu direalisasikan secara efektif

5. Hak yang diklaim tidak bertentangan dengan hak-hak asasi lainnya.

Kriteria tersebut dapat meredam ke-egois-an individu disaat mengklaim "hak" yang ingin terpenuhinya tersebut dan menjadi pembeda antara hak dan kebutuhan. Seorang pekerja sosial yang melakukan praktik dengan pendekatan Hak harus memahami kriteria tersebut, sehingga tidak terjebak dalam kebingungan membedakan antara hak dan kebutuhan.

Dalam konteks praktik berbasis HAM, kebutuhan pada dasarnya bersifat sangat kompleks dan kontroversial. Para penganut positivisme mengangap kebutuhan adalah sebagai hak mereka sendiri yang harus mereka dapatkan sebagai sebuah fenomena yang dapat diidentifikasi dan diukur (Ife, 2002). Kebutuhan memiliki sifat-sifat yang berbeda, sarat nilai. Nilai-nilai yang berbeda di tiap-tiap tempat inilah yang membuat pandangan yang berbeda-beda pula mengenai 'kebutuhan' dan hal-hal yang 'dibutuhkan' dalam situasi atau kondisi tertentu. Kebutuhan harus dipahami sebagai pernyataan nilai-nilai, ideologi, dan bukan hanya sekedar laporan 'fakta'. Dalam pendekatan HAM, hal yang signifikan adalah hak untuk mendefinisikan sendiri kebutuhannya. Jadi individu itu sendiriah yang mengetahui mengenai kebutuhannya, bukan pekerja sosial maupun profesi professional lainnya.

Dalam prosesnya, seorang pekerja sosial harus dapat membedakan antara pendekatan berbasis hak dengan pendekatan berbasis kebutuhan, karena ada beberapa aspek mendasar yang menjadi pembeda kedua pendekatan tersebut. Pembeda tersebut memunculkan peran dan fungsi yang bertolak belakang bagi seorang pekerja sosial dalam melakukan praktik pekerjaan sosial. Zaidalkilani (2010) dalam Apsari (2015:76) menyimpulkan perbedaan mendasar antara pendekatan berbasis hak dengan pendekatan berbasis kebutuhan, sebagai berikut: 
Tabel 2

Perbedaan Antara Pendekatan Berbasis Hak dan Pendekatan Berbasis Kebutuhan

\begin{tabular}{|l|l|}
\hline \multicolumn{1}{|c|}{ Pendekatan berbasis Kebutuhan } & \multicolumn{1}{c|}{ Pendekatan Berbasis Hak } \\
\hline Fokus pada input dan hasil & Fokus pada proses dan hasil \\
\hline Menekankan pada pemenuhan kebutuhan & Menekankan pada merealisasikan hak \\
\hline $\begin{array}{l}\text { Mengakui kebutuhan sebagai permintaan yang } \\
\text { sah }\end{array}$ & $\begin{array}{l}\text { Mengakui hak individual dan kelompok } \\
\text { sebagai tuntutan kepada pemangku kewajiban } \\
\text { secara hukum dan moral }\end{array}$ \\
\hline $\begin{array}{l}\text { Individu-individu adalah objek dari } \\
\text { pengembangan intervensi }\end{array}$ & $\begin{array}{l}\text { Individu-individu dan kelompok diberdayakan } \\
\text { untuk dapat menuntut hak-hak mereka }\end{array}$ \\
\hline Individu layak mendapatkan bantuan & Individu berhak atas bantuan \\
\hline Fokus pada penyebab utama masalah & $\begin{array}{l}\text { Fokus pada penyebab struktural dan } \\
\text { manifestasinya }\end{array}$ \\
\hline $\begin{array}{l}\text { Orang-orang boleh berpartisipasi, tapi pada } \\
\text { umumnya, kemajuan terjadi pada mereka dan } \\
\text { mereka mengambil peran pasif dan tergantung }\end{array}$ & $\begin{array}{l}\text { Orang-orang adalah partisipan aktif dalam } \\
\text { proses kemajuannya dan partisipasi mereka } \\
\text { adalah berperan penting jika ingin ada } \\
\text { kemajuan }\end{array}$ \\
\hline $\begin{array}{l}\text { Sumber daya-sumber daya jarang tersedia, } \\
\text { sehingga beberapa individu akan tidak } \\
\text { terhindarkan tidak mendapatkan akses }\end{array}$ & $\begin{array}{l}\text { Semua orang, tanpa diskriminasi memiliki hak } \\
\text { untuk mencapai potensinya bahkan dengan } \\
\text { sumber daya-sumber daya yang terbatas }\end{array}$ \\
\hline
\end{tabular}

Sumber: Apsari (2015:76)

Dengan berdasarkan pada perbedaan antara kedua pendekatan tersebut, terlihat bahwa di masa kini, pekerja sosial yang menggunakan pendekatan berbasis hak bersifat memberdayakan klien dan mendampingi klien untuk mendapatkan layanan langsung maupun mengubah kebijakan yang membuat mereka tidak mendapatkan keadilan sosial.

Ketika kita membuat pernyataan kebutuhan, artinya kita sedang mengatakan bahwa ada sesuatu yang diperlukan agar sesuatu yang lain dapat terjadi. Sebuah tujuan sebenarnya adalah sarana untuk pecapaian tujuan lain yang diinginkan. Dengan demikian, terdapat dua hal yang perlu diperhatikan tentang kebutuhan. Pertama, adalah bahwa beberapa tujuan yang diinginkan dapat dianggap lebih penting daripada yang lain dan yang lainnya mungkin dipertanyakan mengenai apakah hal-hal yang kita butuhkan itu apa benar-benar 'dibutuhkan' atau sebenarnya kebutuhan kita tersebut hanya cara untuk mencapai tujuan yang diinginkan.

Ketika pekerja sosial membuat pernyataan mengenai kebutuhan, keadaan yang terjadi pada akhirnya adalah bahwa hakhak kemudian di klaim. Dan ini merupakan esesnsi dari hubungan antara kebutuhan dan hak-hak dalam praktik pekerjaan sosial. Contohnya saja, saat kita mengatakan bahwa para masyarakat membutuhkan tempat penitipan anak, maka kita mendasarkan pernyataan pada asumsi mengenai hak-hak orang tua untuk dapat berpartisipasi di tempat kerja atau memiliki waktu lain dan anaknya akan mendapatkan pengasuhan yang cukup dari tempat penitipan anak. 
Oleh karena itu, kebutuhan, dalam praktik pekerjaan sosial itu juga merupakan pernyataan-pernyataan mengenai hak. Masalahnya adalah hak-hak yang terkait hampir selalu implisit dan tidak tertulis. Kebutuhan dan hak merupakan hal yang sangat mirip dan terkadang orang-orang mengatakan hal-hal yang dibutuhkannya adalah sebagai haknya. Titik penting dalam hal ini adalah bahwa antara hak dan kebutuhan tidak mudah untuk ditetapkan prioritasnya terhadap klaim hak dan bahwa hal ini tidak dapat dilakukan tanpa pemeriksaan konteks di mana suatu hak diklaim

Hasil lain dari perspektif hak dan kebutuhan adalah dalam masyarakat multikultural, ada kemungkinan berbagai cara di mana HAM dapat dipenuhi dan dijamin, untuk komunitas budaya yang berbeda. Ada nilai yang jelas dalam keragaman, dan yang penting adalah bahwa praktik HAM seharusnya tidak berusaha untuk memaksakan sebuah sistem yang seragam pada seluruh masyarakat yang berbeda.

Berbicara mengenai kata 'kebutuhan', berasal dari ide yang dibutuhkan, disertai dengan ide sesuatu yang harus dilakukan untuk pemenuhan kebutuhan tersebut. Suatu hak dilihat sebagai akhir dan kebutuhan manusia yang dipandang sebagai suatu hal yang harus dipenuhi agar pencapaian HAM dapat terealisasi. Perbedaan antara kebutuhan sebagai sarana dan dan kebutuhan sebagai suatu tujuan dalam hal ini bagaimanapun tidak jelas. Salah satu contohnya adalah ketika individu memerlukan baju yang dipandang dapat menopang penampilannya untuk terlihat pintar, tapi terlihat pintar itu bukanlah sebuah akhir (atau hak), itu hanya cara lain agar orang lain akan percaya dan dapat menghormati individu tersebut dalam pekerjaannya.

Perbedaan antara hak dan kebutuhan demikian penting, dan meskipun dalam beberapa hal kita menghadapi kesulitan secara konseptual, termasuk permasalahan dalam menentukan antara sarana dan tujuan. Namun, hal ini adalah sebuah bagian penting dari praktik pekerjaan sosial berbasis HAM. Dengan menggunakan kriteria hak asasi manusia yang dapat diklaim oleh individu, seorang pekerja sosial dapat terus berlatih untuk menggunakan bahasa hak daripada kebutuhan disaat bekerja dengan klien. Dengan menggunakan bahasa dan istilah hak, maka klien tidak lagi menjadi sasaran pasif yang hanya mengikuti apa yang disarankan oleh seorang pekerja sosial, tetapi mendorong klien untuk secara aktif mengidentifikasi dan menentukan arah hubungan kerja klien-pekerja sosial untuk mencapai keadilan sosial.

\section{Simpulan}

Jika HAM bersifat universal, maka seorang individu tidak hanya berhak untuk mendapatkan hak-haknya, tetapi juga harus menghormati hak orang lain dan memungkinkan orang lain untuk mendapatkan hak-haknya tersebut. Menerima kerangka hak, 
berarti tidak dapat diartikan hanya sikap egois

pada bagian diri individu saja, menuntut hanya untuk diri sendiri sambil tidak menghargai hak orang lain.

Dengan demikian, berbicara mengenai HAM, artinya tidak hanya berbicara mengenai "apa yang diperlukan untuk membuat seseorang menjadi manusia sepenuhnya", tapi mereka juga "perlu untuk menjadikan manusia sebagai satu masyarakat yang sepenuhnya manusia”. Kita tidak hanya memiliki HAM untuk kepentingan diri kita sendiri, tetapi untuk kepentingan masyarakat di mana kita hidup dan untuk kemanusiaan secara keseluruhan. Praktisi pekerjaan sosial yang menggunakan pendekatan berbasis hak, menggunakan deklarasi dan konvensi hak yang merupakan konsensus bersama sebagai dasar pada saat bekerja bersama klien. Berdasarkan hal tersebut, maka praktik pekerjaan sosial yang menggunakan pendekatan berbasis hak, secara otomatis telah mengakomodir hak-hak asasi manusia dan dapat meminimalkan pelanggaran hak asasi manusia serta mendorong tercapainya keadilan sosial sehingga setiap individu memiliki kesempatan untuk berfungsi secara sosial dan menjadi sejahtera.

\section{Daftar Pustaka}

\section{Buku}

Apsari, N.C. 2015. Hak Anak: Perspektif Pekerjaan Sosial, Bandung: Unpad Press.

Fatic, A. 1995, Punishment and Restorative Crime-Handling: A Social Theory of Trust, Aldershot, UK: Avebury.

Ife, J., 2002, Community Development: Community-based Alternatives in an Age of Globalisation, Melbourne: Pearson.

-------, 2008, Human Rights and Social Work; Towards Rights-Based Practice, Cambridge University Press.

Tutu, D. 1999, No Future Without Forgiveness, London: Random House.

\section{Disertasi}

Apsari, N.C. 2015. Pemenuhan Hak Anak Pasca Reunifikasi. Program Doktoral Kesejahteraan Sosial FISIP, Universitas Padjadjaran: Bandung. 